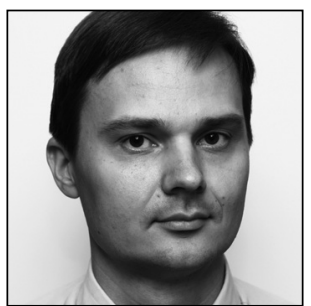

Mait Laaring

Adviser to the Chancellor of Justice

\title{
On the Situation of Law-enforcement Law in Estonia"
}

\section{Introduction}

Of the elements of the special part of Estonian administrative law, law-enforcement law has been one of the most controversial and debated areas in the past decade. This is due to the protracted and still ongoing law-enforcement law reform, particularly that involving the Order Protection Act (OPA), developed and adopted in the course of that reform. ${ }^{{ }_{2}}$

Law-enforcement law regulates the activity of the state in the performance of one of its most basic and important functions - the immediate and mainly preventive assurance of a group of legal rights that can be summed up as public order-and, accordingly, exists at least in its most elementary form in every legal system. Estonia is no exception to this rule: in our legal order, law-enforcement law existed-fragmentarily and inconsistently, but indisputably-in the form of the Police Act and some state supervision acts addressing various specialist fields already at the time of the restoration of our national independence. ${ }^{* 3}$ However, this legal foundation was in dire need of amendment and supplementation in accordance with the principles of a state based on the rule of law. ${ }^{*}$ Preparations for the complete reformation and harmonisation of the law-enforcement law were already underway in the late 1990s, hand in hand with the development of the acts that form the general part of Estonian administrative law. Since then, the concept for the OPA draft has gone through several fundamental changes. ${ }^{*} 5$

1 The article is based on the talk 'Ohutõrje- e. korrakaitseõiguse olukorrast Eestis' (or 'On the situation of threat-countering or law-enforcement law in Estonia') given by the author at the conference At the Sources of Modern Public AdministrationSources, Developments and Perspectives in Estonia and Germany, held on 24- 25 October 2013 in the assembly hall of the University of Tartu within the framework of Academica-the German-Estonian Academic Week. A video recording of the talk, in Estonian, is available at http://www.uttv.ee/naita?id=18306 (most recently accessed on 31.1.2014).

2 Korrakaitseseadus. - RT I, 22.3.2011, 4 (in Estonian).

3 For an overview of the principles and structure of Estonian law-enforcement law in the 1990s, see, for example, I. Koolmeister, K. Orion. Haldussund kehtivas õiguses ['Enforcement of administrative legislation as regulated by the law in force']. Juridica 1998/8, p. $382 \mathrm{ff}$. (in Estonian). For one possible interpretation of the problems and bases of this legal model, see, for example, M. Ernits. Preventiivhaldus kui tulevikumudel ['Proactive administration as a future model']. - Riigikogu Toimetised 17 (2008), p. $156 \mathrm{ff}$. (in Estonian).

4 See also M. Niemeier. Nõuded õigusriiklikule politseiõigusele - proportsionaalsuse põhimõte ja Euroopa õigus ['Requirements for police law: The principle of proportionality and European law']. - Juridica 2004/7, p. 461 ff. (in Estonian).

5 See, for example, KorS-i eelnõu (eelnõu nr 49 SE I) seletuskiri ['Explanatory memorandum on the draft Act of Order Protection (draft $49 \mathrm{SE} \mathrm{I}$ )'], pp. 6-7. Available at http://www.riigikogu.ee/?page=eelnou\&op=ems\&emshelp=true\&eid=9350 $2 \& u=20120331103845$ (in Estonian) (most recently accessed on 31.1.2014). 


\section{The current state of the law-enforcement law reform}

The first stage of the law-enforcement law reform materialised on 1 January 2010, when the new Police and Border Guard Act ${ }^{*}$ (PBGA) came into force. However, this act introduced the revised principles of lawenforcement activity only at the level of the police as a law-enforcement authority, ignoring the specialist fields of law-enforcement law.

The second stage of the reform, which extends the renewed principles to the activity of other law-enforcement authorities (various boards and inspectorates), should materialise upon the entry into force of the OPA. The act in question was passed by Parliament on 23.2.20117\% however, since its enforcement requires dozens of special laws to be amended to a greater or lesser degree, it was decided to prepare a separate implementing act for that purpose. At this point, the draft version of that act too-the draft act for the amendment and application of the Law Enforcement Act ${ }^{* 8}$ (or 'the AAA OPA draft') - has entered legislative proceedings and passed its first reading before the Riigikogu. ${ }^{*} \mathrm{~A}$ fundamental decision about when the new law-enforcement law concept will take effect in full and the current ambiguous situation will end should, therefore, be reached in the near future.

Even though such initially unplanned gradual implementation of the reform is positive in the sense that it makes it possible to test the strengths and weaknesses of the new regulation model in more limited circumstances, it has without doubt also generated additional problems by dividing the existing lawenforcement law into two rather different parts. The police force has de lege lata found itself in an ambivalent position, wherein it needs to proceed from completely different rules and conceptual apparatus in its PBGA-based activities as compared to its supervisory activity as a special law-enforcement authority on the basis of specific laws.

To conclude an overview of the current state of the reform, one could mention that some development in numerous other framework acts of fields falling under the special part of administrative law, such as the General Part of the Economic Activities Code Act ${ }^{* 10}$ and the General Part of the Environmental Code Act ${ }^{* 11}$, has already taken place with the OPA in mind.

\section{The substance of the new law-enforcement law}

In the discussion that follows, a brief overview is given of the main principles serving as the basis for Estonia's new law-enforcement law in the PBGA and OPA.

Firstly, the OPA is an attempt to regulate the whole area of law enforcement in a uniform manner by providing a general framework for the system of defending law-enforcement rights as a whole.

Secondly, that foundation currently being developed is clearly based on the idea of a preventive defence of the right to protection-i.e., public order. ${ }^{*}{ }^{2}$

Thirdly, Estonia's new law-enforcement law is, in essence, threat-countering law. The OPA and PBGA distinguish among certain phases of threats of harm to the various rights to protection, with the central probabilistic threshold being threat or specific threat. Where there is deemed to be a threat, a harmful consequence for the right of protection is sufficiently probable in the near future according to an ex ante

6 Politsei ja piirivalve seadus. - RT I, 2009, 26, 159; RT I, 2.7.2013, 18 (in Estonian).

7 The complete text of the OPA in its 23.2.2011 wording is available in English translation at http://www.legaltext.ee/en/ andmebaas/ava.asp? $\mathrm{m}=022$ (most recently accessed on 31.1.2014).

8 Korrakaitseseaduse muutmise ja rakendamise seaduse eelnõu (424 SE) ['Draft act for the amendment and application of the OPA']. Available at http://www.riigikogu.ee/?page=en_vaade\&op=ems\&enr=424SE\&koosseis=12 (most recently accessed on 31.1.2014).

9 At the time of writing of this article (1.2.2014), the AAA OPA is being prepared within the Legal Affairs Committee of the Riigikogu for completion of the second reading. The date planned for the AAA OPA's entry into force is 1.7.2014.

10 Majandustegevuse seadustiku üldosa seadus - RT I, 25.3.2011, 1 (in Estonian).

$11 \quad$ Keskkonnaseadustiku üldosa seadus - RT I, 28.2.2011, 1 (in Estonian).

12 For a more detailed analysis of the concept of public order in the OPA and its connections to the concept of public order in other laws, the Constitution of the Republic of Estonia, the European Convention on Human Rights, and European Union law, see M. Laaring. Avaliku korra mõiste põhiseaduses ['The concept of 'public order' in the Constitution']. - Juridica 2012/4, pp. 247-261 (in Estonian). 
judgement. ${ }^{* 13}$ In simple terms, this means that the average law-enforcement officer performing the assessment must be convinced that harm would occur in the event of unhindered progression of the causal chain. The law obliges everybody to eliminate any threats arising from his person (see §15 (1) of the OPA). If the originator of the threat, or the person liable for public order, fails to eliminate the threat on his own, the law-enforcement authority may, proceeding from the principle of opportunity, perform a threat-countering procedure, also employing measures that infringe on fundamental rights if these are necessary.

Although the core of law enforcement, pursuant to the new acts of law, consists in addressing the issues of detecting and countering specific threats, the new model does not involve only threat-countering law; to a certain extent, it also involves the prevention of threats-that is, acting on levels of probability lower than that of a specific threat or merely on the basis of an abstract threat. ${ }^{*}{ }^{14}$ The application of measures that infringe on fundamental rights is not ruled out in cases of prevention of specific threats either; however, the possibilities are more limited than with countering of a threat, mostly consisting in the collection of information on the possibility of a specific threat emerging. In particular, threat-prevention-related amendments to the OPA at the level of general principles of law enforcement, along with the powers (measures) of law enforcement, have been provided for with the AAA OPA. Alas, some of the most controversial issues surrounding the legal concept, to which we will later return, arise in relation to the sphere of threat prevention, among other areas.

The OPA proceeds from a clear distinction between law-enforcement competence (law-enforcement function) and law-enforcement powers (law-enforcement measures), providing for the institutions of a general law-enforcement competence (in §6 (2) of the OPA) and a preliminary law-enforcement competence (see $\$ 6$ (2) of the OPA). The law-enforcement competence of state authorities is clearly distinguished from the competence applied in offence-related proceedings (see §1 (4) of the OPA).

The majority of the text of the act addresses the elements necessary for various state supervision measures (powers) on the basis of division of the measures into general and special measures (in Chapter 3 of the OPA).

It is hard to deny that this model, laid out in very broad strokes, bears an important resemblance to the basic structures of German classic threat-countering law, which has served as a model intentionally applied in the reform. However, these elements have not been mechanically carried over into Estonian lawenforcement law; instead, an attempt has been made to adapt the threat-countering to our circumstances, mainly by further elaborating on its essence and by defining individual concepts in order to compensate for the different background in law dogmatics and the different historical perspective.

\section{Problems}

Compared to the progress of reform to other parts of administrative law, that of the reform of Estonian law-enforcement law has been slow and laborious. It is no secret that the processing of the OPA draft has been accompanied by fairly serious debates as to what concept of law enforcement is fitting for the Estonian legal order, not to mention the particulars of the concept chosen. ${ }^{*} 5$ Without an overview of the main points of such criticism, a description of the current state of Estonian law-enforcement law would be incomplete. Although the passing of the OPA marked a fundamental decision that its positive aspects outweigh the potential drawbacks, the discussion has, in effect, continued even as the implementing act has proceeded through the system.

13 On the concept of threat in the OPA, see the explanatory memorandum on the OPA (Note 5), p. 22 ff. See also J. Jäätma. The Constitutional requirements for averting of a threat: The principles of a state based on democracy, and the rule of law v. averting of a threat. - Juridica International 2012/1, pp. 135-144.

14 The concept of abstract threat is here taken to refer to an imaginary threat as opposed to an actually existing specific threat. On threat prevention in the OPA, see also M. Laaring. Estonian law-enforcement law as threat-prevention law. - Juridica International 2013/1, pp. 197-205.

15 For criticism of the new concept, see, for instance, V. Linde. Korrakaitseseaduse eelnõu probleemidest ['About the problems of the Order Protection Act']. - Riigikogu Toimetised 17 (2008), pp. 45-47 (in Estonian); A. Seppik. Kas meil on vaja korrakaitseseadust? ['Do we need the Order Protection Act?']. - Riigikogu Toimetised 17 (2008), pp. 48-49 (in Estonian). The opinion of the Supreme Court on the AAA OPA draft is available at http://www.riigikogu.ee/?page=en_vaade\&op=ems\&e $\mathrm{nr}=424 \mathrm{SE} \&$ koosseis $=12$ (in Estonian) (most recently accessed on 31.1.2014). For a view that is supportive of the concept of threat-countering but critical of the delegation of law-enforcement tasks to private persons, see M. Ernits (Note 3). 
Here, in turn, it is possible to distinguish among several distinct layers of issues. Given the limitations on the length of this article, making generalisations and bringing out only the most characteristic layers are unavoidable. I now proceed, while acknowledging the possibly subjective character of my opinion, to distinguish among five groups of issues.

1. For a long time, the subject that aroused the fiercest passions and pretty much overshadowed the other discussions related to the new law-enforcement law was the question of the possibilities and extent of involving private citizens in the performance of law-enforcement functions. Among other things, this issue clearly set the political powers in Estonia's Parliament against each other and led to harsh criticism of the relevant provisions by the Chancellor of Justice. ${ }^{*} 6$ Namely, the draft act in its original wording provided for-in the spirit of liberal 'small government' ideas-considerable opportunities to delegate law-enforcement functions of the police and rescue-service agencies, including the task of ensuring security in public places, to persons in private law, especially security undertakings, on the basis of contracts under public law. ${ }^{* 17}$ Concluding such a contract would also have allowed, with some restrictions, the application of law-enforcement measures infringing on fundamental rights, along with coercive measures aimed at their assurance against third persons by a person in private law who is tasked with ensuring public order. The issue has, in the end, been resolved through the removal from the OPA of the text pertaining to contractual delegation of law-enforcement functions; this has eliminated the most important obstacle to adoption of the act. However, by way of compromise, the act still contains a general reference to the possibility of such delegation, as long as the bases and procedure for it are provided by a specific law (see $\S 82$ of the OPA). Hence, the question of delegation has not definitively lost its relevance and may arise again when the circumstances change. The Supreme Court of Estonia has so far not had a chance to express its opinion clearly on the matter of where the line is to be drawn between acceptable and unacceptable co-operation between the public and private sector in the law-enforcement field, the main factor in the restriction of delegation involving the necessity to maintain the state monopoly on force. ${ }^{*}{ }^{8}$ The court has nevertheless implied that the constitutional restrictions that apply to the performance of 'administrative activities of supervisory nature'-i.e., in essence, to the delegation of the law-enforcement function-may not be as strict as those applying to the transfer of penal authority with regard to offence proceedings. The latter has been ruled out by the court altogether. ${ }^{* 19}$

As for the concept serving as a basis for law-enforcement law as a whole, that too has engendered lively debate among politicians and lawyers alike.

2. The arguments by which the chosen concept is alien and therefore incompatible with the traditions of Estonian administrative law can probably be treated as related to feasibility in legal-political terms, rather than criticism based on the Constitution. ${ }^{* 20}$ As life has shown, the Riigikogu has, in fact, shaped legal policy in a different manner. The fact that proceeding from a threat-countering model is not entirely unprecedented, at least in our legal theory, is confirmed by, for instance, a glance at the police-law-related views of A.-T. Kliimann, the most renowned administrative-law theorist of Estonia's previous time of independence. ${ }^{{ }^{21}}$ However, it cannot be denied that the question of whether the legal concept has developed through long-term evolution of domestic law or been taken over from the outside as a novel whole may affect the assessment of the constitutionality of the regulation (see the following paragraphs).

3. The legal clarity-but also the legal certainty in general-of the provisions of the OPA has met with significant criticism. ${ }^{* 22}$ It is clear that the implementation of the new law-enforcement model, espe-

16 See, for example, the overview of the activity of the Chancellor of Justice in 2006 that is available at http://oiguskantsler. ee/en/2006 (most recently accessed on 31.1.2014), specifically p. $75 \mathrm{ff}$.

17 See §§81-91 of the OPA draft in its original wording and the explanatory memorandum on them (Note 5).

18 On transfer of the state monopoly on force with reference to restriction to the delegation of public duties to persons in public law in the Estonian legal order, see N. Parrest. Constitutional boundaries of transfer of public functions to [the] private sector in Estonia. - Juridica International 2009/1, p. $48 \mathrm{ff}$.

19 SCenbancd 3-1-1-86-07, of 16.5.2008, para. 26 (in Estonian).

20 Opinion of the Supreme Court on the AAA OPA draft (see Note 15), p. 1.

21 For example, see R. Eliaser (ed.). Haldusõiguse üldosa. Autoriseeritud konspekt. A.-T. Kliimanni loengute põhjal ['General Part of Administrative Law: Authorised Notes, Based on Lectures by A.-T. Kliimann']. Tartu 1939, pp. 205-206 (in Estonian).

22 See, for example, Linde (Note 15), pp. 45-46. 
cially application of the highly abstract concepts of threat and public order, means the introduction of a much higher degree of abstraction in law-enforcement activities than was seen in the former legal thought of the legislator just as much as the implementer of the law. The concomitant potential uncertainty is, in turn, exacerbated by further widening of the space for discretion through a clear emphasis on the principle of opportunity in deciding on the implementation of these measures and in acting in the individual stages of the application thereof. What has merited particular criticism is the general law-enforcement competence (see $\$ 28$ of the OPA) as allowing for very broad discretion-it is seen as unacceptably vague in terms of both the grounds for its application and its legal consequences. ${ }^{*}{ }^{23}$ Where a threat-countering model is used, the ability of a law-enforcement officer to interpret and implement the law, assess the likelihood of harm, and weigh the various rights against each other, all properly, plays a much bigger role, therefore. Also, the predictability of the activity of law-enforcement authorities for the targets of the measures and, ultimately, the opportunity of higher agencies and the courts to control the actions of the officers may decrease.

It must be admitted that comprehensiveness and flexibility of law enforcement, which is one clear goal behind the abstractness of the regulation, has a certain price, which cannot be mitigated in our branch of law through long-time defining and elaboration activity of legal practice and science-the factors that the German Federal Constitutional Court has pointed out as the main guarantees of the legal clarity of the general provisions for law enforcement in German law. ${ }^{* 24}$ This fear also finds support from the quite common background conviction that the ability of Estonian law-enforcement officers to apply their right of discretion flawlessly is not very great in the first place. ${ }^{* 25}$

4. In addition to legal certainty, the widening of the set of measures available to the police and other law-enforcement authorities, relative to the earlier domestic-security law, has made the perennial main question of infringement management-that of the balance between the rights to be protected and those infringed upon (i.e., of moderation of infringement)-more relevant than ever before. There have been doubts as to the level of seriousness of infringements on fundamental rights that could possibly be justified by the prevention-oriented necessity to protect legal rights, which is necessarily characterised by uncertainty of the progression of the causal chain. ${ }^{* 26}$ The criterion of a specific threat or its qualified forms also has been considered too uncertain and subjective to be able to serve as a balancing point in infringement on fundamental rights in the case of more infringing measures such as bringing in forcefully, searching, or coming onto the premises, even in the event of a properly executed assessment of threat. This approach has led opponents to the conviction that any infringements on fundamental rights that venture even slightly toward the more serious side are admissible only post factum and in the framework not of administrative procedure but of offence proceedings, where the proportional relations between various rights are clearer, there is more time for assessment, and the person whose rights are being infringed on has greater legal guarantees in the form of court proceedings. ${ }^{{ }^{2} 27}$ Alternatively, such infringements are considered possible outside offence-related proceedings only in an extraordinary legal situation-e.g., in a state of emergency, wherein powers allowing for greater infringement of fundamental rights are applied. The conviction that more serious infringements on fundamental rights are admissible only in the framework of offence-related proceedings seems also to be reflected in the fact that the legislator has tried to treat some measures that are applied in especially sensitive areas as part of penal proceedings, despite their purpose, which is mainly law-enforcement-oriented. An example of this is the way surveillance activities (covert information-processing measures) targeted at 'preventing and blocking', or, in the later formulation, 'detection and prevention', of criminal offences are treated in the Code of Criminal Procedure. ${ }^{{ }^{2} 8}$

23 On the possibilities for interpretation of constitutionality, see K. Eller. Korrakaitse üldvolituse koosseis Saksa õiguses ja Eesti korrakaitseseaduse eesnõus ['General authorisation in the maintenance of law and order in German law and in the Estonian draft of the Maintenance of Law and Order Act']. - Juridica 2007/1, pp. 41-53 (in Estonian).

24 Bundesverfassungsgericht 23.05.1980, 2 BvR 854/79. - Entscheidungen des Bundesverfassungsgerichtes 54, p. 143 (and 144ff).

25 O. Kask. Korrakaitse seaduse eelnõust ['About the order protection draft act']. - Juridica 2004/7, p. 469 (in Estonian).

26 See Linde (Note 15), p. 46.

27 Ibid.

28 This question is actually more complex, since the purpose of these measures can be regarded as something between a preventive and a repressive one. See also S. Laos. Chapter 11.2.1. - E. Kergandberg, P. Pikamäe (eds). Kriminaalmenetuse seadustik. 
In the case of probability of harm that falls short of a specific threat, the assessment of the balance of rights to be protected and infringed on is even more difficult than in cases of probability of harm arising from a specific threat. Some discussion has been sparked by the question of what requirements should be set for infringements that occur in the course of a so-called routine check in the event of abstract threat, or in other cases wherein the probability of harm is below the threshold for sufficient probability that characterises specific threats but providing for a possibility of intervention by the legislator seems necessary. Whether this requires separate justification by means of a so-called abstract threat prediction, as provided for in the AAA OPA draft ${ }^{* 29}$, has been debated, as have whether coercive measures may be applied to ensure this, which measures those might be, etc.

5. Lastly, we take a look at a criticism that has elements in common with all of the critical points raised above. It calls into doubt the ability of a law-enforcement law concept built on the idea of threat to serve as a basis for the system of protecting public order as a whole. In other words, it has been found that the protection of public order should be seen as divided into two parts, where one of these partsso-called inspectional (or traditional) state supervision-should omit any reference to threat and/or its preliminary stages. ${ }^{*} 30$

In Estonia's current legal tradition, inspectional supervision has been understood mostly as a routine supervisory activity, independent of any specific threat, that is carried out by special lawenforcement authorities-boards and inspectorates-and directed, above all, at the detection and elimination of offences that have already occurred. This sphere of activity has been weakly connected to the sphere of police activity. Unlike, for example, German law-enforcement law, the special fields of law enforcement in Estonia have not taken shape in an evolutionary manner, through a gradual separation from general police law. Rather, they have assumed a position alongside it through an independent path of development. Police law (in its narrower sense) has not developed to form the general part of law-enforcement law. This may be one of the sources of the idea that law-enforcement law in its entirety cannot be brought under a single common denominator.

From the perspective of law enforcement that uses the concept of threat as a core threshold, inspectional state supervision consists mostly in threat prevention: application of measures in a situation wherein no data exist (yet) on the occurrence of a specific threat or in dealing with already committed breaches of public order-above all, the implementation of administrative coercion for their elimination. It is clear that a security model based on countering only specific, already developed threats cannot ultimately ensure performance of the state's duty of protection of individuals. Hence, it has never been an objective of the OPA to rule out supervisory activity of law-enforcement authorities aimed at preventing specific threats, let alone at rectifying offences that have already occurred. An attempt has been made to integrate inspectional supervision into the act together with other elements of preventing specific threats.

However, the regulation of detecting and preventing specific threats has remained as the core of the concept, and we can agree with the critics that the density of the regulation of inspectional state supervision in the OPA (even after its supplementation with the implementing act) is rather low. This can be partially overcome through reliance on the general provisions on administrative proceedings as set forth in the Administrative Procedure Act ${ }^{*}{ }^{31}$, but this option is clearly limited. A rational kernel of the criticism can certainly be found in the fact also that we must not overdo the unification of law-enforcement law if that means sacrificing the necessary and distinctive features of special fields to abstraction.

Kommenteeritud väljaanne ['Code of Criminal Procedure, Commented Edition']. Tallinn: Juura 2012, pp. 305-306 (in Estonian).

29 See the explanatory memorandum on the draft AAA OPA (Note 8), p. $10 \mathrm{ff}$.

30 Opinion of the Supreme Court on the AAA OPA draft (Note 15), p. 2 ff.

$3^{1}$ Haldusmenetluse seadus. - RT I, 2001, 58, 354; RT I 23.2.2011, 3 (in Estonian). 


\section{Conclusions}

In highlighting certain points of contention, the discussion above is meant only to clarify the current state of the debate. The limited length of this article does not permit their analysis in more depth, much less the fleshing out of any clear opinion. A definitive answer to many of these questions can arise only out of the constitutional review practice of the Supreme Court, once the OPA enters into force in its present basic form.

In the application of the parts of the PBGA, effective since 2010, that are related to law-enforcement procedure, the fears associated with the ability of police officers to understand the new act of law properly and apply the broader right of discretion correctly have so far not been validated, at least as far as the author of this article is aware. The training provided has certainly played a part in this.

I tend to believe that, regardless of the problems, the elaboration of the OPA has, all in all, been quite a useful experience for the development of the Estonian legal system and legal science, even if only for the fact that it has provided, and continues to provide, an opportunity to debate and shape clear views on some questions of fundamental importance to the construction of the legal system, such as those of the relationship between prevention and repression, the involvement of persons in private law in the performance of the core functions of the state, and the feasibility and limits of our legal tradition versus the reception of foreign law. The positions clarified in relation to the OPA may well prevent the same arguments from arising in the future.

It is also clear that the realisation of the reform-in whichever form it finally takes-will not lead Estonian law-enforcement law into a situation wherein we could neglect to advance it for a longer time. The rapidly changing security environment, with new threats and risks, has made police and law-enforcement law a rapidly developing part of administrative law in several European countries over the past few decades. To see that development, one need only take a look at the changes that have taken place in German and Nordic law, for example. Estonian law cannot be an exception. It must increasingly follow the general tendencies as European integration continues to deepen. A proactive and preventive approach, data processing, and the use of technological advancements are keywords whose importance in our law-enforcement law will most likely continue to grow. Some of its questionable aspects notwithstanding, the OPA is equipped to serve as a foundation for these developments. ${ }^{*} 32$

32 For example, R. Poscher. Eingriffsschwellen im Recht der inneren Sicherheit ['Legal thresholds for imposing security measures in internal security law']. - Die Verwaltung 2008/3, pp. 345-373 (in German); E. Husabø. Counterterrorism and the expansion of proactive police powers in the Nordic states. - Journal of Scandinavian Studies in Criminology and Crime Prevention 2013/1, pp. 3-23. - DOI: http://dx.doi.org/10.1080/14043858.2013.773759. 